\title{
Z działalności polskiego radiowywiadu na kierunku niemieckim w latach trzydziestych XX w.
}

\begin{abstract}
Abstrakt: Artykuł omawia organizację oraz efekty działalności polskiego radiowywiadu na kierunku niemieckim w latach trzydziestych XX w. Przedstawia kulisy złamania przez polskich matematyków szyfrów Enigmy. Dzięki temu znaczącemu sukcesowi Oddział II SGWP uzyskał wiele cennych informacji o sytuacji wojskowo-politycznej III Rzeszy. Ukazano też współpracę wywiadu wojskowego II RP ze służbami specjalnymi Francji i Wielkiej Brytanii na płaszczyźnie radiowywiadowczej. Tekst systematyzuje i uściśla dotychczasową wiedzę na temat prac polskiego Biura Szyfrów w zakresie dekryptażu Enigmy.
\end{abstract}

Słow a kluczowe: polski wywiad wojskowy, radiowywiad, Enigma, współpraca radiowywiadowcza.

Abstract: The article discusses the organisation and effects of Polish radio intelligence operations on the German direction in the 1930s. It presents the inside story of the breaking of Enigma codes by Polish mathematicians. Thanks to this significant success, the Second Department of the Polish General Staff obtained a great deal of valuable information about the military and political situation of the Third Reich. Also, the cooperation between the Polish military intelligence and special services of France and Great Britain in radio intelligence is depicted. The text systematises and clarifies our knowledge of the work of the Polish Cipher Bureau in the field of Enigma decryption.

Keyw ords: Polish military intelligence, radio intelligence, Enigma, radio intelligence cooperation. 
Ważne miejsce w pracy Oddziału II Sztabu Głównego (do 1928 r. Generalnego) Wojska Polskiego (SGWP) zajmował radiowywiad, który odegrał istotna rolę w okresie walk o granice II Rzeczypospolitej, ujawniając najbardziej tajne zamiary nieprzyjaciela. W ogromnym stopniu przyczynił się przede wszystkim do zwycięstwa nad Armią Czerwoną w 1920 r. Radiowywiad był nowoczesnym środkiem uzyskiwania wartościowych informacji nie tylko o charakterze wojskowym, ale również politycznym i ekonomicznym. Stanowił nieodzowny dział pracy polskiego wywiadu wojskowego. Cechą wiadomości pochodzących z radiowywiadu - w opinii analityków „dwójki” z początku lat trzydziestych - była ich wiarygodność. Dane te pozwalały na sprawdzenie, uzupełnienie, względnie wyjaśnienie wiadomości zdobytych z różnych źródeł. $\mathrm{Z}$ reguły też wyprzedzały inne informacje ${ }^{1}$.

Działalność radiowywiadu polegała na uzyskiwaniu wiadomości o potencjalnym przeciwniku na podstawie danych zdobywanych za pomoca podsłuchu i dekryptażu korespondencji radiotelegraficznej oraz rozpoznania radiostacji przez prowadzenie pomiarów goniometrycznych, które określały miejsca nadawania, jak też ewidencji odbieranych sygnałów radiotelegraficznych i wzajemnej łączności. Polski radiowywiad wniósł znaczny wkład w rozpoznanie rozbudowy sił zbrojnych III Rzeszy i przygotowań wojennych tego państwa. Dotyczyło to zwłaszcza następujacych zagadnień: a) ustalanie O.de.B - w tym głównie identyfikacji nowych jednostek i ich dyslokacji; b) obserwacja manewrów i ćwiczeń, kiedy to praca radiostacji była szczególnie aktywna; c) rozpoznanie niemieckiej łączności radiowej przez wskazywanie miejsc postoju stacji radiowych, ich przydziałów i podziału na kategorie; d) uzyskanie szeregu cennych wiadomości z dziedziny uzbrojenia i przemysłu zbrojeniowego ${ }^{2}$. Niezależnie uzyskał wiele wiadomości na temat działalności służby bezpieczeństwa - Sicherheitsdienst des Reichsführers SS (SD) czy też cenne informacje m.in. odnośnie do przygotowań do zajęcia Austrii oraz agresji na Polskę.

Na czele Biura Szyfrów stał wybitny oficer WP ppłk dypl. Gwido Langer, kierujacy tym pionem Oddziału II od 15 IX 1929 r. Radiowywiadem na Niemcy i łamaniem szyfrów niemieckich zajmował się Referat B.S.4. Za jego pracę odpowiedzialny był mjr Maksymilian Ciężki. Należał on niewątpliwie do grona najbardziej zasłużonych osób, które przyczyniły się do złamania szyfrów Enigmy. Z Oddziałem II związany był od marca 1923 r. Oficjalnie

\footnotetext{
${ }^{1}$ Centralne Archiwum Wojskowe Wojskowego Biura Historycznego w Warszawie-Rembertowie (dalej: CAW WBH), Oddział II Sztabu Głównego (Generalnego) Wojska Polskiego z lat 1921-1939 (dalej: Oddział II SGWP), I.303.4.1734, Sprawozdanie z pracy Wydziału III za lata 1929-1931, [b.d.].

${ }^{2}$ Archiwum Instytutu Polskiego i Muzeum im. gen. Sikorskiego w Londynie (dalej: AIPMS), B.I.6l, Sprawozdanie mjr. Maksymiliana Ciężkiego z 29 IV 1940 r.; CAW WBH (dawne WBBH, MiD), I/3/60, Ppłk dypl. L. Sadowski, Oddział II Sztabu Głównego. Rezultaty pracy pokojowej i udział w przygotowaniach do wojny, mps, s. 81 .
} 
kierownictwo referatu niemieckiego objął 1 I 1933 r. ${ }^{3}$ W Biurze Szyfrów pełnił też funkcję zastępcy Langera. Siedziba Referatu B.S.4 znajdowała się od września 1937 r. w nowoczesnym ośrodku w Pyrach pod Warszawa, gdzie jego personel miał odpowiednie warunki do pracy. Wcześniej mieściła się w Pałacu Saskim, w którym ulokowana była centrala polskiego wywiadu wojskowego ${ }^{4}$.

Dla celów podsłuchowych B.S.4 korzystało głównie z trzech stałych stacji radiotelegraficznych: nr $3 \mathrm{w}$ Krzesławicach, nr 4 w Poznaniu, nr 5 w Starogardzie ${ }^{5}$. Aby wzmocnić obserwację Prus Wschodnich i Morza Bałtyckiego w okresie poprzedzajacym wojnę, przystapiono do organizacji kolejnej - w Białymstoku, lecz prace nad jej utworzeniem nie zostały zakończone ${ }^{6}$.

Stacje radiotelegraficzne natychmiast przekazywały przechwycony pilny materiał droga telegraficzna albo radiotelegraficzna, natomiast normalny był codziennie dostarczany pocztą kurierska przy wykorzystaniu pociagów, które miały bezpośrednie połączenie z Warszawa. Zastosowanie tej metody dawało gwarancję, że „zdobyty materiał przez stacje już kilka godzin później znajdował się na warsztacie właściwej ekipy kryptologicznej [...]. Do ostatniej chwili przed wybuchem wojny ten dział służby łącznie z kryptologia wnosił stale pewną ilość materiału informacyjnego, uzupełniającego obraz sytuacji nieprzyjacielskiej"7. Ponieważ własne stacje podsłuchowe nie były w stanie opanować całokształtu pracy stacji niemieckich, zwłaszcza ulokowanych w zachodniej i południowej części, strona polska otrzymywała materiał radiowywiadowczy i szyfrowy z francuskiego i - w okresie współpracy - z czechosłowackiego radiowywiadu ${ }^{8}$. W 1939 r. dostarczali go także Brytyjczycy ${ }^{9}$.

\footnotetext{
${ }^{3}$ AIPMS, B.I.6l, Sprawozdanie mjr. Maksymiliana Ciężkiego z 29 IV 1940 r.

${ }^{4}$ W ośrodku w Pyrach znajdowała się też nowoczesna radiostacja „G” Oddziału II, podlegająca pod względem organizacyjnym i służbowym kierownikowi Biura Szyfrów. Kierował nia (od 1936 r., kiedy trwały jeszcze prace budowlane i montażowe) kpt. Franciszek Sobecki. Zadaniem radiostacji było przede wszystkim na wypadek wojny zapewnienie Naczelnemu Dowództwu stałej łączności z placówkami zagranicznymi oraz sztabami państw sprzymierzonych i zaprzyjaźnionych. Zainstalowane zostały również przy radiostacji G odbiorniki systemu Hella, które umożliwiały przejmowanie komunikatów nadawanych przez Niemieckie Biuro Informacyjne (DNB). Ibidem, Załącznik do zeszytu ewidencyjnego kpt. Franciszka Sobeckiego z 29 XI 1939 r.

${ }^{5} \mathrm{~W}$ sumie Biuro Szyfrów dysponowało siedmioma stacjami radiotelegraficznymi. Pozostałe rozmieszczono następująco: $\mathrm{nr} 1 \mathrm{w}$ Warszawie, $\mathrm{nr} 2 \mathrm{w}$ Lidzie, $\mathrm{nr} 6 \mathrm{w}$ Równem i nr 7 w Kołomyi.

${ }^{6}$ AIPMS, B.I.6g, Załącznik do zeszytu ewidencyjnego podpułkownika dyplomowanego Stefana Mayera z 29 X 1939 r. Sieć tą uzupełniały ruchome grupy podsłuchowe do wykrywania szpiegowskich radiostacji oraz drużyny kontrwywiadu radiowego. Biuro Szyfrów miało cztery ruchome grupy podsłuchowe. Zamierzano utworzyć piąta, tak aby jedna przypadała na dwa okręgi korpusu. Ibidem.

7 Ibidem.

${ }^{8}$ Zob. P. Kołakowski, Między Warszawa a Praga. Polsko-czechostowackie stosunki wojskowo-polityczne 1918-1939, Warszawa 2009, s. 327-355.

${ }^{9}$ AIPMS, B.I.6l, Sprawozdanie mjr. Maksymiliana Ciężkiego z 29 IV 1940 r.
} 
W latach dwudziestych polski radiowywiad nie miał kłopotów z łamaniem niemieckich szyfrów transpozycyjnych. Również w późniejszym okresie były one rozwiązywane, lecz Niemcy używali ich w niewielkim stopniu. W Oddziale II liczono jednak, jak przyznał ppłk dypl. Stefan Mayer, że w przypadku wybuchu wojny zostana oni zmuszeni do szerszego wykorzystania tej metody, co - jak wiemy - nie nastapiło ${ }^{10}$. Problemy pojawiły się dopiero po wprowadzeniu w Reichswehrze wynalezionej przez dr. inż. Arthura Scherbiusa elektromechanicznej maszyny szyfrującej o nazwie Enigma. Uznawana była przez Niemców za niezawodny środek do przekazywania tajnych informacji, bowiem gwarantowała możliwość ich kodowania w astronomicznej wprost liczbie kombinacji. W 1926 r. ulepszone egzemplarze Enigmy trafiły do marynarki wojennej - Reichsmarine, a dwa lata później, czyli w 1928 r., do wojsk lądowych - Reichsheer, stając się stopniowo podstawowym systemem szyfrowania $\mathrm{w}$ niemieckich siłach zbrojnych. Od połowy lat trzydziestych wykorzystywano ją również $\mathrm{w}$ lotnictwie. Znalazła się też na wyposażeniu m.in. policji i SD. Należy pamiętać, iż poszczególne rodzaje Enigmy były wielokrotnie modyfikowane ${ }^{11}$.

Zastosowanie maszynowego szyfru w Reichsheer zwróciło uwagę polskich kryptologów, którzy w 1928 r. podjęli pierwsze prace nad złamaniem Enigmy. Były one prowadzone przez zespół składający się z por. Ciężkiego, por. Wiktora Michałowskiego, który miał znaczne osiagnięcia w łamaniu niemieckich szyfrów transpozycyjnych, oraz cywilnego pracownika o nazwisku Czajsner ${ }^{12}$. Ich działania nie zakończyły się sukcesem. Ciężki miał sięgnać nawet po niekonwencjonalne metody, konsultując problem ze znanym ówcześnie w Polsce specjalista od zjawisk paranormalnych, inż. Stefanem Ossowieckim. W końcu zdecydowano się na przeprowadzenie kursu kryptologicznego dla wyróżniającej się grupy studentów matematyki Uniwersytetu Poznańskiego, którzy dobrze znali język niemiecki, co później okazało się kluczową decyzją w złamaniu Enigmy. Spośród 23 jego uczestników wybrano kilku najbardziej utalentowanych, którzy od 1 X 1929 r. w specjalnie zorganizowanej dla nich poznańskiej ekspozyturze Referatu Radiowywiadu (szyfry obce na Niemcy), a następnie Biura Szyfrów, mieszczącej się w podziemiach Komendy Miasta przy ul. Świętego Marcina, podjęli pracę nad przechwyconymi przez stacje radiotelegraficzne niemieckimi szyframi, zdobywając w ten sposób potrzebne

${ }^{10}$ Ibidem, B.I.6g, Załącznik do zeszytu ewidencyjnego podpułkownika dyplomowanego Stefana Mayera z 29 X 1939 r.

11 J.S. Ciechanowski, J. Tebinka, Wspótpraca kryptologiczna Enigma, w: Polsko-brytyjska wspótpraca wywiadowcza podczas II wojny światowej, t. I: Ustalenia Polsko-Brytyjskiej Komisji Historycznej, red. T. Dubicki, D. Nałęcz, T. Stirling, Warszawa 2004, s. 443-444.

${ }^{12}$ M. Grajek, Enigma. Bliżej prawdy, Poznań 2007, s. 43. Inni autorzy zamiast Czajsnera wymieniają w tym gronie inż. Antoniego Pallutha. J.S. Ciechanowski, Polski wkład w złamanie niemieckiej maszyny szyfrujacej Enigma, w: Marian Rejewski 1905-1980. Życie Enigma pisane, Bydgoszcz 2005, s. 101. 
doświadczenie ${ }^{13}$. Wśród nich znaleźli się Jerzy Różycki i Henryk Zygalski. Jako ostatni do grupy tej dołączył Marian Rejewski, który w 1929 r. wyjechał na studia do Getyngi, a po ich przerwaniu i powrocie do kraju w 1930 r. został asystentem prof. Zdzisława Krygowskiego - dyrektora Instytutu Matematyki. W 1932 r. Oddział II zlikwidował ekspozyturę poznańska, a najlepszych spośród młodych kryptologów: Rejewskiego, Różyckiego i Zygalskiego z dniem 1 września tego roku na stałe zatrudniono w Biurze Szyfrów w Warszawie. Pracowali w ścisłej tajemnicy w niewielkim pomieszczeniu Pałacu Saskiego, a ich pierwszym sukcesem było rozwiązanie czteroliterowego kodu niemieckiej marynarki wojennej ${ }^{14}$.

Pierwszy szyfrogram Enigmy został odczytany przez Rejewskiego pomiędzy świętami Bożego Narodzenia 1932 r. a Nowym Rokiem 1933. Był to jednak o czym musimy pamiętać - początek długiej i trudnej drogi. Do sukcesu, oprócz dogłębnej wiedzy matematycznej, intuicji, determinacji i błyskotliwych założeń zespołu, przyczyniły się odtworzenie wewnętrznej konstrukcji maszyny szyfrujacej i opracowanie metod odtwarzania kluczy szyfrowanych depesz. Część informacji niezbędnych do ogólnego zapoznania się z jej budową polscy kryptolodzy uzyskali, analizując handlowy, mniej skomplikowany od wersji wojskowej model Enigmy. W 1929 r. Niemcy przez przypadek wysłali do Polski wersję komercyjna, która przed zwróceniem została rozebrana na części i zbadana, a w 1932 r. udało się ją zakupić. Doprowadził do tego związany z Biurem Szyfrów inż. Antoni Palluth, mający zasługi w sukcesach kryptologicznych, a także współwłaściciel Wytwórni Radiotechnicznej AVA, która produkowała sprzęt radiowy dla WP, w tym również dla Oddziału $\mathrm{II}^{15}$. Następnie dokonano przeróbek w wersji handlowej Enigmy i rozpoczęto prace nad własnymi kopiami urządzenia ${ }^{16}$. W poznaniu tajemnicy niemieckiej maszyny szyfrujaccej niezwykle istotne były informacje dostarczone przez wywiad. Główną rolę

${ }^{13}$ Zob. Z.J. Kapera, Poznański kurs szyfrów obcych w 1929 r., w: Wywiad wojskowy II Rzeczypospolitej. Materiały, red. P. Kołakowski, A. Pepłoński, Kraków 2011, s. 108-110. Według ustaleń tego autora kurs szyfrów obcych (niemieckich), oficjalnie organizowany przez DOK nr VII w Poznaniu, trwał od stycznia do marca 1929 r. Ibidem, s. 102, 105-106.

14 Szerzej zob. M. Grajek, op. cit., s. 43-49; Z.J. Kapera, Marian Rejewski pogromca Enigmy, Kraków-Mogilany 2005, s. 44-46.

15 To nowoczesna firma, która powstała pod koniec lat dwudziestych. Jej właścicielami byli, poza Palluthem, bracia Ludomir i Leonard Danilewiczowie oraz Edward Fokczyński. Początkowo firma mieściła się na ul. Nowy Świat 43, a następnie na ul. Stępińskiej 25. W 1936 r. zatrudniała 20 pracowników umysłowych i 80 fizycznych. Przed wybuchem wojny pracowało w niej już ok. 300 osób. AVA wykonała dla Oddziału II kopie Enigmy, aparaturę nadawczo-odbiorczą dla radiostacji w Pyrach, a także wyprodukowała stacje dla ekspozytur, Samodzielnych Referatów Informacyjnych i agentów. AIPMS, B.I.61, Protokół przesłuchania mjr. Maksymiliana Ciężkiego z 6 III 1940 r.; Ksiq̨̇̇ka informacyjno-adresowa „Cała Warszawa”, Warszawa 1930; G. Łukomski, Poznańskie poczatki „Enigmy”, „Mars” 2001, t. X, s. 6-7.

${ }^{16}$ M. Grajek, op. cit., s. 53, 78. 
odegrało współdziałanie z francuskimi służbami specjalnymi, bowiem kierownik Sekcji D (szyfry i dekryptaż) Service de Renseignements kpt. Gustave Bertrand przekazał w 1932 r. dwa dokumenty „o nadzwyczajnym znaczeniu. Pierwszy z nich nosił tytuł „Instrukcja obstugi szyfru maszynowego, drugi zaś zawierał tzw. klucze dnia na miesiące październik i grudzień 1931 roku. [...] Należy podkreślić, że posiadanie dokumentów, a zwłaszcza klucza dziennego, w rozstrzygający sposób wpłynęło na postęp prac. Bez nich złamanie szyfru Enigmy opóźniłoby się o kilka lat. Jednocześnie należy zauważyć, że ani służbom francuskim, ani angielskim nie udało się złamać szyfru, mimo że obie dysponowały opisanymi dokumentami"17. Materiały te pochodziły od cennego agenta Hansa-Thilo Schmidta, ps. Asché, wówczas pracownika niemieckiego Centrum Szyfrów (Chiffrierstelle) Reichswehry. Do pracy w tej komórce przyjęty został dzięki bratu, mjr. Rudolfowi Schmidtowi, późniejszemu generałowi. „Asché” przekazał wiele materiałów dotyczących Enigmy, jak też tajnych informacji dyplomatycznych i wojskowych odnośnie do zamiarów III Rzeszy ${ }^{18}$.

Od 1933 r. Polacy zaczęli regularnie czytać niemieckie depesze szyfrowane przy użyciu Enigmy, wypracowując odpowiednią metodę deszyfrażu. Już w 1934 r. dysponowano kilkunastoma jej replikami skonstruowanymi pod nadzorem kpt. Ciężkiego i inż. Pallutha w firmie AVA, które „miały ułatwić odczytywanie bieżace przechwyconego materiału depesz"19. Złamanie niemieckiej maszyny szyfrującej należy zaliczyć do największych osiagnięć polskiego wywiadu wojskowego. Przed wybuchem II wojny światowej jedynie Polacy czytali Enigmę, trzeba jednak pamiętać, że jej złamanie nie było jednorazowym sukcesem, bowiem Niemcy ciagle wprowadzali skomplikowane ulepszenia, z którymi musiano - nie bez poważnych kłopotów - uporać się. Na przykład od 1 II 1936 r. kolejność wirników zmieniano co miesiąc, a od 1 października tego roku nawet codziennie. Pojawiały się też nowe sieci radiowe używające Enigmy, operujące jednak odmiennymi kluczami dziennymi. I tak niemieckie lotnictwo utworzyło 1 VIII 1935 r. własną sieć radiową. Również od września 1937 r. dysponowała nią SD. W sieci tej wprowadzono z czasem kilka nowości ${ }^{20}$. Zdarzało się też Niemcom popełniać poważne nieostrożności, dzięki którym Biuro Szyfrów mogło przygotować się na zmiany. We wrześniu 1937 r. przez nieuwagę wspomniano w depeszach o zamiarze wprowadzenia tzw. reflektora B, którego zaczęto używać od 2 listopada tego roku ${ }^{21}$.

\footnotetext{
17 Sztafeta Enigmy. Odnaleziony raport polskich kryptologów, red., oprac. i tłum. M. Grajek, Warszawa-Emów 2017, s. 159.

18 W 1943 r. został on zdradzony przez zatrzymanego przez Niemców współpracownika francuskiego wywiadu, Rodolphe’a Lemoine'a, ps. Rex, który nawiązał z nim kontakt i odbywał spotkania.

${ }_{19}$ AIPMS, B.I.6g, Załącznik do zeszytu ewidencyjnego podpułkownika dyplomowanego Stefana Mayera z 29 X 1939 r.; J.S. Ciechanowski, op. cit., s. 103-104.

20 Sztafeta Enigmy..., s. 169.

${ }^{21}$ Ibidem.
} 
Innym razem wykorzystano niekonsekwencje szyfrantów Kriegsmarine przy zmianie procedury szyfrowania, która nastapiła 1 V 1937 r. Odtąd indywidualny klucz depeszy nie był szyfrowany za pomocą maszyny, ale zewnętrznego podstawienia, niezależnego od Enigmy. Jednak oprócz zachowania wcześniejszych ustawień wewnętrznych jeden $\mathrm{z}$ okrętów nie został $\mathrm{w}$ porę wyposażony $\mathrm{w}$ instrukcję użycia nowej procedury i posługiwał się przez kilka dni stara, rozpracowana przez B.S.4. Pozwoliło to na odczytanie wielu depesz niemieckiej marynarki wojennej z pierwszych dni maja 1937 r. oraz na określenie sposobu szyfrowania klucza depeszy ${ }^{22}$.

W latach 1933-1935 z dekryptażu Enigmy zdobyto sporo wartościowych informacji o sytuacji wojskowo-politycznej Rzeszy Niemieckiej. Materiał uzyskiwany z tego źródła był różnorodny. $\mathrm{Z}$ odczytanych szyfrogramów posiadano dane na temat tworzenia nowych jednostek wojskowych, organizacji, uzbrojenia i wyszkolenia Reichswehry, zachodzacych zmian w dyslokacji, przydziałów służbowych, przygotowań mobilizacyjnych, prac fortyfikacyjnych i rozbudowy przemysłu zbrojeniowego. Należy zauważyć, że były to niekiedy wiadomości fragmentaryczne, jednak nie umniejszało to ich znaczenia ${ }^{23}$. W połowie $1934 \mathrm{r}$. przechwycono również wiele cennych informacji o „nocy długich noży", kiedy Hitler przystapił do brutalnej rozprawy z kierownictwem SA (Oddziałów Szturmowych NSDAP) ${ }^{24}$.

Z tego źródła pochodziły też istotne wiadomości dotyczące remilitaryzacji Nadrenii w marcu $1936 \mathrm{r}$. oraz zaangażowania III Rzeszy w wojnę domowa w Hiszpanii. Z odnalezionej notatki sporządzonej przez Samodzielny Referat „Niemcy” dla szefa Oddziału II z 4 XI 1936 r. możemy dowiedzieć się, jakie informacje uzyskano z Enigmy pomiędzy 25 lipca a 18 września tego roku. Dotyczyły one przede wszystkim prac osłonowych Heeresdienststelle I w Szczecinku. Z kolei przechwycona korespondencja dowództwa II Korpusu z Heeresdienststelle II w Wałczu oraz inspekcji poborowej w Szczecinie informowała o obsadzaniu stanowisk w dowództwach odcinków osłonowych przez oficerów i podoficerów w stanie spoczynku. Kolejne informacje wskazywały na przeprowadzaną reorganizację Grenzschutzu i gromadzenie zapasów amunicji i broni dla oddziałów osłonowych przez zakłady uzbrojenia w Opolu, Świdnicy, Legnicy, Głogowie i Olsztynie. „Przedstawiając powyższe dane - napisał mjr dypl. Wincenty Sobociński - melduję, że sa to dla nas wiadomości cenne. Większa ilość takich informacji mogłaby rzucić dużo światła na przygotowania w dziedzinie mob. materiałowego zwłaszcza”. Kierownik Samodzielnego Referatu „Niemcy”, powołując się na kpt. Ciężkiego, zwracał uwagę, iż wiadomości pochodzące z Biura Szyfrów były „w dużej ilości” nieprzepracowane i stanowiły zaledwie znikomą część tego, co znajdowało się w jego posiadaniu.

\footnotetext{
${ }^{22}$ Ibidem, s. 181-182.

${ }^{23}$ AIPMS, B.I.6l, Sprawozdanie mjr. Maksymiliana Ciężkiego z 29 IV 1940 r.

${ }^{24}$ J.S. Ciechanowski, op. cit., s. 104.
} 
Natomiast materiał przepracowany trafiał do komórki analitycznej z dużym, bo dwumiesięcznym opóźnieniem ${ }^{25}$.

Dzięki złamaniu Enigmy możliwe było śledzenie intensywnie prowadzonej rozbudowy Wehrmachtu oraz przygotowań wojennych III Rzeszy. Skupiano się przede wszystkim, co jest zrozumiałe, na meldunkach i rozkazach wojsk lądowych i lotnictwa, a w mniejszym stopniu marynarki wojennej, gdzie do 16 XI 1936 r. czytano tylko ok. jedną dziesiąta depesz ${ }^{26}$. Dotyczyły m.in. tworzenia nowych jednostek i ich przemieszczeń, przydziałów, uzbrojenia, wyszkolenia oraz przygotowań mobilizacyjnych. W tym miejscu warto zacytować byłego szefa Wydziału Wywiadowczego, płk. dypl. Mayera, któremu podlegał radiowywiad. W sporządzonym w $1974 \mathrm{r}$. memorandum napisał, że w 1937 r. „nasi kryptolodzy całkowicie opanowali metodę przechwytywania i odczytywania niemieckich radiogramów szyfrowanych przez Enigmę. W styczniu 1938 r. wykonano dwutygodniowe badania nad rozszyfrowaniem przechwyconych materiałów Enigmy. Wówczas rozszyfrowano ok. $75 \%$ tych materiałów"27.

Radiowywiad dostarczył również ciekawych informacji na temat operacji zajęcia przez Wehrmacht Austrii w marcu 1938 r. ${ }^{28} \mathrm{Z}$ tego źródła pochodziły także cenne wiadomości na temat mobilizacji i koncentracji oddziałów policji bioracych udział w aneksji tego kraju. Z przechwyconej 15 marca depeszy wynikało, że następnego dnia z Linzu miano wysłać eskadrę myśliwców do Monachium w celu eskortowania samolotu, którym udawał się Adolf Hitler do Berlina. Do września 1938 r. były czytane sieci łączności wojsk lądowych, Luftwaffe, służby bezpieczeństwa i marynarki ${ }^{29}$. Major Ciężki w sprawozdaniu z kwietnia 1940 r. napisał trafnie o działalności B.S.4, że w okresie wypowiedzenia traktatu wersalskiego, intensywnej rozbudowy wojskowo-organizacyjnej III Rzeszy, likwidacji Austrii i przygotowań do zajęcia Sudetów „rozwiązany

${ }^{25}$ Wagę materiałów pochodzących z radiowywiadu podkreślał również mjr dypl. Jan Leśniak, który zastapił w 1938 r. na stanowisku kierownika Samodzielnego Referatu „Niemcy” Sobocińskiego. Według jego przekazu informacje te napływały jednak do podległej mu komórki z różnym natężeniem. R. Woytak, Werble historii, Bydgoszcz 1999, s. 114.

${ }^{26}$ J.S. Ciechanowski, op. cit., s. 104; Sztafeta Enigmy..., s. 181.

${ }^{27}$ Relacja bytego szefa polskiego wywiadu o ztamaniu Enigmy z $31 \mathrm{~V} 1974$ roku, oprac. J. Tebinka, w: Marian Rejewski..., s. 209. Zdzisław Kapera zwrócił uwagę, iż ze wspomnień Rejewskiego wynika, że aby odczytywać 90\% depesz, wystarczyło tylko zatrudnić więcej radiotelegrafistów i wyszkolić dodatkowych kryptologów. Z.J. Kapera, Marian Rejewski..., s. 50 .

${ }^{28}$ CAW WBH, I/3/60, Ppłk dypl. L. Sadowski, Oddział II Sztabu Głównego..., s. 81.

${ }^{29}$ Ppłk dypl. Ludwik Sadowski, wskazując na sukcesy B.S.4, stwierdził: „Na ogół do roku 1938 praca radiowywiadu i szyfrów niemieckich stanowiła cenny wkład rozpoznania rozbudowy sił zbrojnych Niemiec przez Wydział Studiów Oddziału II [...]. Stwierdzić trzeba, że radiowywiad [...] mógł się poszczycić pokaźnymi wynikami pracy pokojowej, prawdopodobnie przewyższającymi rezultaty identycznych organów w sztabach alianckich”. Ibidem, s. 81,83 . 
i wykorzystany materiał szyfrowy stanowił bardzo poważne źródło informacyjne [...]. Niemal 100\% dostarczonych wiadomości okazało się słusznymi i ścisłymi, niekiedy zaś zawierały tak bardzo zastanawiające rewelacje, że uznano za stosowne sprawdzenie ich przez własny wywiad ofensywny. Bardzo często materiał ten stanowił impuls dla skierowania przez Biuro Studiów własnego wywiadu ofensywnego na właściwe tory"30.

Sytuacja uległa zmianie 15 IX 1938 r., gdy Niemcy wprowadzili nowa procedurę szyfrowania, będąca zagrożeniem dla dotychczasowych osiagnięć polskich kryptologów ${ }^{31}$. Polegała ona na tym, że nie istniała jedna i ta sama pozycja bazowa dla wszystkich depesz wymienianych w ciagu dnia, lecz zmieniała się ona z depeszy na depeszę. Odpowiedzią na te zmiany po dogłębnych analizach miała być bomba Rejewskiego, czyli urządzenie składające się z sześciu maszyn Enigma, które były napędzane elektrycznie i zatrzymywały się automatycznie w momencie, gdy osiagnęły rozwiązanie. W Biurze Szyfrów przystapiono do zmontowania sześciu egzemplarzy takiej bomby. Kiedy znajdowały się one w budowie, Niemcy dokonali dalszych zmian. Mianowicie w grudniu $1938 \mathrm{r}$. wprowadzono dwa nowe wirniki i zwiększono liczbę par połączeń w łacznicy. W wyniku tych zmian bomby utraciły swoje znaczenie. Pracownicy B.S.4 opracowali wówczas tzw. płachty Zygalskiego, które pozwoliłyby na praktyczne rozwiązanie problemu. Ręcznie wyprodukowano tylko dwa komplety po 26 płacht, co było czasochłonne i kłopotliwe, bowiem wymagało odpowiedniej aparatury, z czym Biuro Szyfrów Oddziału II SGWP nie mogło sobie poradzićic ${ }^{32}$.

O możliwości wprowadzenia tych zmian przez Niemców polski wywiad wojskowy został poinformowany latem 1938 r. Wiadomość pochodziła od bardzo cennego agenta bydgoskiej ekspozytury nr „1210”, Ottona Bacha, pracującego w służbie łączności Luftwaffe w Magdeburgu. Przekazał on instrukcję szyfrowa, z której wynikało, że w razie nieuniknionego nadejścia wojny niemieckie dowództwo zamierzało użyć w Enigmie kolejnych dwóch bębenków. Ponadto agent ten dostarczył Oddziałowi II charakterystyki techniczne i opis sprzętu radiowego używanego w całym lotnictwie ${ }^{33}$.

Nie oznacza to, że w B.S.4 od drugiej połowy września 1938 r. do wybuchu wojny w 1939 r. zupełnie przestano czytać Enigmę. Mayer stwierdził, że do ostatniej chwili przed rozpętaniem wojny przez III Rzeszę radiowywiad „łącznie z kryptologią wnosił stale pewną ilość materiału informacyjnego, uzupełniając

\footnotetext{
${ }^{30}$ AIPMS, B.I.6l, Sprawozdanie mjr. Maksymiliana Ciężkiego z 29 IV 1940 r.

$31 \mathrm{~W}$ ocenie ppłk. dypl. Mayera zmiany wprowadzone przez Niemców w tym czasie mogły być spowodowane z jednej strony daleko posuniętą ostrożnością z ich strony, a z drugiej „niezbyt zgrabną akcją wywiadowczą na ich maszynę szyfrową przeprowadzoną przez naszych sprzymierzeńców”, co rzeczywiście było planowane przez Francuzów. Ibidem, B.I.6g, Załącznik do zeszytu ewidencyjnego podpułkownika dyplomowanego Stefana Mayera z 29 X 1939 r.

32 Sztafeta Enigmy..., s. 170-173.

${ }^{33}$ Relacja bytego szefa polskiego wywiadu o złamaniu Enigmy..., s. 209-210.
} 
obraz sytuacji nieprzyjacielskiej"34. Odczytywano przede wszystkim depesze $\mathrm{SD}$, gdzie nie obowiazywała nowa procedura szyfrowania, wprowadzona 15 IX 1938 r. w wojskach lądowych i lotnictwie. Informacje pochodzące $\mathrm{z}$ tej sieci były niezwykle wartościowe. Uzyskiwano wiadomości na temat nastrojów wewnętrznych w III Rzeszy, niemieckiej dywersji politycznej na Słowacji, Rusi Zakarpackiej, w Kłajpedzie i na Litwie oraz we Francji i Wielkiej Brytanii, a także w Polsce. Często informacje dotyczyły agentów służby bezpieczeństwa działających poza Niemcami, dzięki czemu można było odtworzyć rozgałęzione siatki szpiegowskie. Z tego źródła kontrwywiad otrzymał cenne dane na temat agentury niemieckiej funkcjonujacej na ziemiach polskich i wykorzystywania mniejszości niemieckiej do akcji wywiadowczej i dywersyjnej. Jednak 1 VIII 1939 r. również w sieci SD nastapiła całkowita zmiana procedury, której nie zdążono już rozpracować ${ }^{35}$.

We wrześniu 1938 r., w okresie akcji sudeckiej, B.S.4 przekazało wiele informacji dotyczących intensywnej pracy grup stacji polowych i lotniczych w Prusach Wschodnich, na Pomorzu, jak też w Brandenburgii, Saksonii i na Śląsku, przesyłających depesze szyfrowe i krótkie meldunki sytuacyjne. $\mathrm{Z}$ niektórych wynikało, że na pograniczu polskim odbywały się ćwiczenia, przy czym jako cele natarcia wymieniano m.in. Augustów, Grodno i Nowogród. Stwierdzono prowadzenie obserwacji ziem polskich przez lotnictwo na Ślasku. 13 IX 1938 r. Biuro Szyfrów poinformowało o próbnej mobilizacji przeprowadzonej 11 dni wcześniej w Olsztynie - rezerwiści zostali powołani w nocy telefonicznie i po kilku godzinach zwolnieni. 15 września doniesiono, że poprzedniego dnia odbyła się w Berlinie odprawa oficerów policji z okręgów Poczdam i Frankfurt nad Odra, podczas której przedstawiano stany personalne i wykazy samochodów. 21 tego miesiąca stwierdzono ożywioną pracę radiostacji niemieckich przy granicy z Czechosłowacją. Również w późniejszym okresie notowano wzmożoną ich działalność na tym obszarze. Dotyczyło to także stacji policyjnych. Od 24 września niektórzy funkcjonariusze policji z poszczególnych okręgów mieli pozostawać w pogotowiu do dyspozycji ministra spraw wewnętrznych. 5 X 1938 r. B.S.4 poinformowało, iż z otwartych depesz wysłanych 30 września i 1 października wynikało, że siedziba komendanta Policji Porządkowej gen. Kurta Daluegego znajdowała się w Dreźnie ${ }^{36}$.

Niezwykle ciekawa była depesza ekspozytury gestapo w Nadrenii, nadana 29 IX 1938 r. do centrali w Berlinie, ilustrująca nastroje ludności. Informacje $\mathrm{w}$ niej zawarte potwierdzały doniesienia wywiadu głębokiego z drugiej połowy

${ }^{34}$ AIPMS, B.I.6g, Załącznik do zeszytu ewidencyjnego podpułkownika dyplomowanego Stefana Mayera z 29 X 1939 r.

${ }^{35}$ Ibidem, B.I.6l, Sprawozdanie mjr. Maksymiliana Ciężkiego z 29 IV 1940 r.; Sztafeta Enigmy..., s. 178.

${ }^{36}$ Więcej informacji na temat pracy polskiego radiowywiadu w tym czasie będzie można znaleźć w przygotowywanej przez autora artykułu książce o działalności polskiego wywiadu wojskowego na Niemcy hitlerowskie. 
tego miesiąca. Według depeszy nastroje wśród mieszkańców Frankfurtu nad Menem „pozostawiały dużo do życzenia”. Podczas wymarszu oddziałów SS widziano - jak to określono - „przykre sceny”, gdy żony i dzieci biegły z płaczem za kolumna, domagając się, aby mężowie i ojcowie pozostali w domu. Wydarzenia te miały wywrzeć na ludności, która przyglądała się wymarszowi formacji SS, nadzwyczaj przykre oraz przygnębiające wrażenie. Wśród powołanych do wojska rezerwistów zdarzały się przypadki oświadczeń, że nie wyrusza z koszar ze swoimi oddziałami, dopóki nie zostaną uregulowane kwestie zabezpieczenia bytu ich rodzin. Zauważono, że informacje prasowe oraz radiowe, szczególnie urzędowo-partyjne, przyjmowane były z dużą rezerwa, a ludność słuchała głównie audycji zagranicznych. Wiadomości o konferencji w Godesbergu przekazano w niemieckiej prasie i radiu w skrócie oraz z dużym opóźnieniem. Zwrócono tėz uwagę na prowadzenie przez księży katolickich akcji mającej na celu wzbudzenie w społeczeństwie sympatii wobec Czechów.

Przed wkroczeniem wojsk niemieckich do Czecho-Słowacji B.S.4 informowało 14 III 1939 r. o ograniczeniu do minimum korespondencji przez stałe stacje wojskowe i SA. Z kolei 18 marca, po odczytaniu szyfrogramu, meldowano, że minister spraw wewnętrznych Rzeszy Wilhelm Frick przebywał dwa dni wcześniej w Pradze, natomiast jego samochody służbowe pozostały w Monachium, skąd miały być skierowane w dalszą drogę. Również 18 marca Biuro Szyfrów donosiło o koncentracji floty wojennej w Kilonii. Tego samego dnia przekazano też inną ważną wiadomość - być może pochodząca z dekryptażu Enigmy - o zaopatrywaniu „od pewnego czasu” portów w Piławie i Królewcu w ropę naftowa, która była sprowadzana z Tallinna. 22 III 1939 r. o godz. 21.40 radiowywiad pracujacy na kierunku niemieckim poinformował, iż następnego dnia Niemcy zajmą Kłajpedę. Wiadomość ta potwierdzała doniesienia na ten temat z innych źródeł, napływające od pewnego czasu do centrali polskiego wywiadu wojskowego ${ }^{37}$.

Warto zauważyć, że wiele informacji, niejednokrotnie istotnych, pozyskiwano z nasłuchu stacji radiowych. W ten sposób wychwycono wiadomość nadana 3 kwietnia o godz. 20.00 przez radiostację w Zossen koło Berlina o wydaniu rozkazu wycofania części oddziałów z Czech i Moraw do stałych garnizonów. Było to podyktowane - jak stwierdzono - zaprowadzeniem w Protektoracie „spokoju i porządku”. Ten komunikat radiowy potwierdzał wcześniejsze doniesienia aparatu wywiadowczego ${ }^{38}$.

${ }_{37}$ P. Kołakowski, Czas próby. Polski wywiad wojskowy wobec groźby wybuchu wojny w 1939 roku, Warszawa 2012, s. 132.

${ }^{38}$ CAW WBH, Oddział II SGWP, I.303.4.3900, Sprawozdanie informacyjne nr 25 z 5 IV 1939 r. (6 IV 1939 r.); R. Michulec, Ku wrześniowi 1939, Gdynia 2008, s. 639. Por. A. Woźny, Niemieckie przygotowania do wojny $z$ Polskq $w$ ocenach polskich naczelnych władz wojskowych w latach 1933-1939, Warszawa 2000, s. 260; Z.J. Kapera, Łamanie szyfrów Enigmy przez Polaków. Mity i prawda, „Przegląd Historyczno-Wojskowy” 2005, nr spec. 5, s. 30. 
Cenne dane uzyskano z odszyfrowanego przez polskich kryptologów meldunku praskiej placówki niemieckiej służby wywiadowczej, która informowała Berlin, że przejęte zapasy materiału wojennego i broni armii czecho-słowackiej były dużo większe, niż spodziewano się wcześniej. Na przykład przypuszczano wejść w posiadanie ok. 450 tys. karabinów, gdy tymczasem do 24 III 1939 r. zdążono zabezpieczyć ich ok. miliona, a dalszych 400 tys. znajdowało się w końcowym stadium wykończenia w fabrykach. Przejęto też 18 tys. koni, co pozwoliło rozwiązać $\mathrm{w}$ tym zakresie problemy armii niemieckiej, a także olbrzymie zapasy paszy i owsa, które z powodu trudności transportowych oraz związanych z magazynowaniem w Rzeszy postanowiono pozostawić tymczasowo w Czechach i na Morawach. Ze zdecydowanie negatywną oceną praskiej placówki spotkał się fakt zaopatrywania się żołnierzy, funkcjonariuszy policji i członków organizacji narodowosocjalistycznych w żydowskich sklepach.

W 1939 r. przedstawiono naświetlenie pracy radiostacji niemieckich. W charakterystyce wojskowych stacji stałych stwierdzono, że ich działalność polega na wymianie korespondencji stacji poszczególnych korpusów ze stacja centralna znajdujaccą się przy Ministerstwie Wojny, a także pomiędzy stacjami korpusów, jak i na terenie danego korpusu. Z informacji B.S.4 wynikało, że prawie każdy garnizon posiadał stałą stację radiową. Wymienione radiostacje pracowały codziennie, z wyjątkiem niedziel i świąt, od godz. 6.00 do 19.00 na falach krótkich, średnich i długich. Używały sygnałów trzyznakowych, składających się z liter i cyfr, które codziennie były zmieniane. W korespondencji przekazywały wyłącznie telegramy szyfrowane. Ich praca odbywała się bardzo sprawnie i szybko, co dowodziło, iż ich obsługa została bardzo dobrze wyszkolona. Stacje lotnictwa wojskowego pracowały wyłącznie na falach krótkich ${ }^{39} \mathrm{i}$ w grupach po 10-15 radiostacji, co było spowodowane korespondencją pomiędzy lotniskiem podstawowym a lotniskami pomocniczymi. Codzienne zmieniano ich sygnały, które miały układ jak w stacjach wojsk lądowych. Wymieniały również tylko telegramy szyfrowane, a układ depesz niczym nie różnił się od nadawanych przez radiostacje lądowe ${ }^{40}$. W przypadku wojskowych stacji niestałych w okresie od 20 do 27 IV 1939 r. zanotowano pięć zgrupowań obejmujących Prusy Wschodnie, Pomorze, Brandenburgię i częściowo Ślask oraz Czechy i Morawy. W ich skład wchodziły radiostacje dowództw operacyjnych, wielkich jednostek i niższych dowództw. Pracowały na falach średnich zarówno w dzień, jak i nocy. Używały sygnałów o podobnym charakterze jak stacje stałe, z wyjątkiem lotniczych, które posługiwały się sygnałami pięcioznakowymi. Działalność tych stacji ograniczała się głównie do nawiązywania łączności, a telegramów nadawano stosunkowo mało ${ }^{41}$.

\footnotetext{
${ }^{39}$ Fal dłuższych używano wyłącznie do przekazywania komunikatów meteorologicznych.

${ }^{40}$ CAW WBH, Oddział II SGWP, I.303.4.3886, Radiostacje niemieckie. Opracowanie z 5 IV 1939 r. [winno być 5 V 1939 r.].

${ }^{41}$ Ibidem.
} 
W późniejszym okresie przekazywano również szczegółowe meldunki na temat pracy wojskowych i policyjnych radiostacji ulokowanych w pobliżu granicy z Polska. Major Ciężki stwierdził, że przed agresja „normalna praca niemieckich stacji wojskowych nie wskazywała na [...] przesunięcia oddziałów i koncentrację jednostek wojskowych na wschodniej granicy Niemiec. Nie zauważono w miesiącu sierpniu 1939 roku - mimo stanu czujności, który wprowadzono na stacjach podsłuchowych od 22 maja 1938 r. - nowych stacji wojskowych a zwłaszcza polowych" ${ }^{42}$. Niewątpliwie sytuacja taka utrudniała Oddziałowi II rekonstrukcję przygotowań armii niemieckiej do ataku na państwo polskie.

Wybrane informacje szyfrowane za pomoca Enigmy czytano w B.S.4 do ostatnich dni przed wybuchem wojny. Pod koniec czerwca z dekryptażu Enigmy otrzymano dwie bardzo ważne wiadomości świadczące o zamiarach Niemców. Według pierwszej władze policyjne zabrały się do sporządzania list proskrypcyjnych Polaków, którzy mieli zostać aresztowani po wybuchu wojny. Natomiast druga informacja mówiła o przystapieniu do opracowania planu ewakuacji urzędów z terenu niemieckiego Ślaska w razie podjęcia działań zbrojnych przeciwko II Rzeczypospolitej ${ }^{43}$. Wiadomo też, że udało się złamać jeszcze depesze z 25 VIII 1939 r., czyli dnia powszechnej mobilizacji w III Rzeszy ${ }^{44}$.

Należy zwrócić uwagę, że Biuro Szyfrów w 1939 r. przekazywało na bieżąco szczegółowe informacje na temat ruchu okrętów Kriegsmarine oraz przeprowadzanych ćwiczeń. Komórka ta była de facto podstawowym źródłem wiadomości w tym zakresie, co znajdowało odzwierciedlenie w komunikatach i sprawozdaniach informacyjnych Oddziału II SGWP. Na przykład radiowywiad na podstawie meldunku stacji morskich poinformował, że w dniach 12 i 13 VIII 1939 r. większość jednostek przebywała w portach Zatoki Pomorskiej, Meklemburskiej i Kilońskiej. W Świnoujściu i Bansin znajdowały się: pancernik „Gneisenau”, krążownik „Leipzig”, flotylla szkolna torpedowców i 1 Flotylla Eskortowców. W porcie kołobrzeskim stwierdzono obecność dwóch minowców (M-111 i M-132) z 1 Flotylli oraz flotylli zagrodowców, natomiast w Ustce - torpedowca T-196. Z Piławy w kierunku zachodnim wypłynęły cztery minowce, które 13 sierpnia ok. godz. 17.10 znajdowały się na wysokości Półwyspu Helskiego. Meldowano również o przejściu 1 Flotylli Trawlerów z Morza Północnego na Morze Bałtyckie ${ }^{45}$. 25 sierpnia miało miejsce

\footnotetext{
${ }^{42}$ AIPMS, B.I.6l, Sprawozdanie mjr. Maksymiliana Ciężkiego z 29 IV 1940 r.

${ }^{43}$ P. Kołakowski, Czas próby..., s. 168.

${ }^{44}$ Sztafeta Enigmy..., s. 174. Mayer napisał na ten temat, że dzięki wiedzy polskich kryptologów i zbadaniu przez nich części nowych rozwiązań wprowadzonych przez Niemców „nie straciliśmy całkowicie możności odczytywania depesz niemieckich szyfrowanych na maszynie, ograniczyło się to jednak do tych wypadków, kiedy w użyciu tej maszyny zbiegły się akurat znane nam elementy. Były to jednak wypadki bardzo rzadkie”. AIPMS, B.I.6g, Załacznik do zeszytu ewidencyjnego podpułkownika dyplomowanego Stefana Mayera z 29 X 1939 r.

${ }^{45}$ CAW WBH, Oddział II SGWP, I.303.4.3719, Meldunek sytuacyjny stacji morskich od dnia 12 do 13 VIII $1939 \mathrm{r}$.
} 
przesunięcie znacznych sił morskich z zachodniego na wschodni Bałtyk ${ }^{46}$. Następnego dnia okręty Kriegsmarine przystapiły do patrolowania obszaru pomiędzy Rugia, Bornholmem i Piława. Stwierdzono też ich koncentrację w rejonie od Ławicy Słupskiej do Zatoki Gdańskiej ${ }^{47}$.

Należy wspomnieć, że informacje przekazywane przez Biuro Szyfrów (Referat B.S.4) kodowano w Oddziale II pod kryptonimem placówka „Wicher” lub też rzadziej źródło „Wicher”. Były to nie tylko wiadomości z dekryptażu Enigmy, ale również z nasłuchu radiowego i działalności goniometrycznej, dotyczące głównie ruchu niemieckich okrętów wojennych oraz pracy radiostacji.

$\mathrm{Na}$ początku 1939 r. doszło do nawiązania francusko-brytyjsko-polskiej współpracy na płaszczyźnie kryptologicznej i nasłuchu radiowego. Pierwsze spotkanie poświęcone Enigmie miało miejsce w dniach 9-10 stycznia w Paryżu w siedzibie Service de Renseignements. Zadaniem konferencji, która odbyła się z inicjatywy francuskiej, było przede wszystkim lepsze zintegrowanie współpracy w zakresie łamania niemieckich szyfrów maszynowych. Ze strony polskiej w rozmowach uczestniczyli kierownicy: Biura Szyfrów - ppłk dypl. Langer oraz Referatu B.S.4 - mjr Ciężki. Delegacji brytyjskiej przewodził szef Rządowej Szkoły Kodów i Szyfrów kmdr Alexander „Alastair” Denniston. W jej skład wchodzili kryptolodzy: Hugh Foss i Alfred Dillwyn Knox. Gospodarzy reprezentowali kierownik Sekcji D Bertrand i dwóch ekspertów (jednym z nich był najprawdopodobniej kryptolog kpt. Henri Braquenié). Brytyjczycy - o czym należy wspomnieć - podchodzili do współpracy z Francuzami i Polakami z dość dużą rezerwą i nie od razu zgodzili się na przyjazd do Paryża. Zgodnie z otrzymana instrukcja przedstawiciele polskiego Oddziału II mieli nie ujawniać tajemnicy sukcesu złamania Enigmy pozostałym uczestnikom konferencji, bez przedstawienia przez nich postępów w tej sprawie i gotowości podzielenia się wiedzą w tym zakresie. Okazało się, że Francuzi i Brytyjczycy nie dokonali istotnych postępów w pracach nad niemieckimi szyframi maszynowymi, pomimo dysponowania cennymi dokumentami dotyczącymi samej Enigmy, jak i metod szyfrowania korespondencji. W tej sytuacji polscy oficerowie nie ujawnili osiagnięć kryptologów z B.S.4 ${ }^{48}$. Rozmowy w Paryżu zakończyły się wspólną wizytą u Drouanta - w reprezentacyjnej restauracji lubianej przez oficerów francuskich służb wywiadowczych. Konferencję trafnie podsumował oficer francuskich tajnych służb Paul Paillole: „Przyniosła ona rozczarowanie do strony technicznej. Wszyscy byli powściagliwi co do stanu swoich własnych badań. Jednakże okazała się ona pożyteczna, gdyż umożliwiła przedstawicielom tych trzech państw poznanie się, przedstawienie swych pomysłów i metod

\footnotetext{
${ }^{46}$ Ibidem, I.303.4.3892, Sprawozdanie informacyjne nr 168 z 26 VIII 1939 r. [27 VIII 1939 r.].

${ }^{47}$ Ibidem, Sprawozdanie informacyjne nr 169 z 27 VIII 1939 r. [28 VIII 1939 r.].

${ }^{48}$ Z.J. Kapera, Paryż 1939: tajna konferencja kryptologów alianckich, w: Polski wywiad wojskowy 1918-1945. Materiały, red. P. Kołakowski, A. Pepłoński, Toruń 2006, s. 417-421; P. Kołakowski, Czas próby..., s. 280.
} 
obliczeń, ustalenie systemu łączności i wymiany informacji. Na zakończenie obiecano sobie, bardziej lub mniej szczerze, spotkanie się, dzielenie się owocami trwajacych prac i wymianę przechwytywanych depesz Enigmy"49.

Przełomowe było drugie spotkanie, do którego doszło w Polsce. W obliczu zbliżającej się wojny oraz niemożności przezwyciężenia trudności technicznych, wymagających znacznych nakładów pracy i finansowych, przerastajacych możliwości Biura Szyfrów, podjęto decyzję ujawnienia tajemnicy Enigmy francuskiej i brytyjskiej służbie kryptologicznej. Pod koniec lipca do Warszawy na zaproszenie ppłk. dypl. Langera przyjechali z Francji mjr Bertrand i kpt. Braquenié, a z Wielkiej Brytanii - kmdr Denniston, kryptolog i ekspert od Enigmy Knox oraz kmdr Humphrey Sandwith z radiowywiadu marynarki wojennej, który miał nawiązać współpracę z Oddziałem II w zakresie nasłuchu radiowego Kriegsmarine ${ }^{50}$. Trzydniowa konferencja rozpoczęła się 26 lipca ${ }^{51}$ nieopodal Warszawy w tajnym ośrodku w Pyrach w Lesie Kabackim, gdzie znajdowała się siedziba B.S.4. Ze strony polskiej główną rolę odgrywali kryptolodzy, którzy doprowadzili do złamania Enigmy: Rejewski, Różycki i Zygalski oraz ppłk dypl. Langer i mjr Ciężki. Pokazano Francuzom i Brytyjczykom wyprodukowane przez zakłady AVA kopie Enigmy. Udzielono im również wszelkich objaśnień związanych z deszyfrażem niemieckich szyfrów. Osiagnięcia Biura Szyfrów stanowiły ogromne zaskoczenie dla gości, w tym przede wszystkim członków delegacji brytyjskiej, bowiem mjr Bertrand dowiedział się o nich dzień przed rozpoczęciem oficjalnych rozmów. Na konferencji ustalono też zakres dalszej współpracy. Oddział II przekazał także aliantom po kopii Enigmy, które wraz z inną ważną dokumentacją (jeden komplet, tzw. płachty Zygalskiego, rysunki techniczne bomb i cyklometru) w sierpniu 1939 r. ppłk dypl. Langer przewiózł na Zachód. Kierownik Biura Szyfrów przebywał wówczas nie tylko w Paryżu, ale również w Londynie, gdzie dotarł droga lotnicza ze stolicy Francji. Egzemplarz maszyny szyfrującej, ofiarowany Brytyjczykom przez Polaków, został dostarczony kilka dni później. Przewieźli go pociagiem 16 VIII 1939 r. kierownik paryskiej ekspozytury Secret Intelligence Service

${ }^{49}$ Cyt. za: Z.J. Kapera, Przekazanie aliantom tajemnicy Enigmy (Pyry, lipiec 1939), „Prace Komisji Historii Wojen i Wojskowości Polskiej Akademii Umiejętności” 2009, t. V, s. 91.

50 Jest on określany również jako prof. Sandwich. Funkcjonuje równolegle wersja, jakoby pod tym nazwiskiem krył się płk Stewart G. Menzies z Secret Intelligence Service. Zob. N. West, MI-6. Operacje brytyjskiej Tajnej Stużby Wywiadu 1905-1945, tłum. R. Brzeski, Warszawa 2000, s. 120. O wizycie Menziesa w Pyrach wspominali również Robin Denniston, syn „Alastaira” Dennistona oraz płk dypl. Mayer, który w czasie II wojny światowej spotkał się z nim przypadkowo w Londynie i rozpoznał jako prof. Sandwicha. R. Woytak, op. cit., s. $135-136$.

51 Sztafeta Enigmy..., s. 173; Przekazanie Enigmy aliantom Pyry, lipiec 1939 r. Nowe dokumenty $z$ archiwów brytyjskich, oprac. J.S. Ciechanowski, E. Maresch, w: Marian Rejewski..., s. 225, 235. Powszechnie przyjmuje się w literaturze, że spotkanie odbywało się od 24 do 26 VII 1939 r., z tym iż zasadnicze rozmowy rozpoczęły się rankiem 25 tego miesiąca. Zob. m.in.: M. Grajek, op. cit., s. 132-136. 
(SIS) Wilfred Dunderdale i jego współpracownik Tom Greene w towarzystwie mjr. Bertranda. Na dworcu przesyłkę odebrał płk Stewart G. Menzies, który był wówczas wiceszefem Tajnej Służby Wywiadowczej, a w listopadzie tego roku staną na jej czele ${ }^{52}$.

Poznanie tajemnicy Enigmy stanowiło jeden z najważniejszych sukcesów polskiego wywiadu wojskowego w działalności na kierunku niemieckim. Przed wybuchem II wojny światowej jedynie Polacy czytali informacje szyfrowane za pomoca tej maszyny. Należy jednak pamiętać, że jej złamanie nie było jednorazowym sukcesem, bowiem Niemcy ciagle wprowadzali skomplikowane ulepszenia, z którymi - nie bez poważnych kłopotów - musiano się uporać. Udostępnienie przez Oddział II SGWP wiedzy na temat Enigmy zwiększało przewagę aliantów w starciu z hitlerowskimi Niemcami i przyczyniło się $\mathrm{w}$ istotny sposób do zwycięstwa nad nimi.

\section{Streszczenie}

Ważne miejsce w pracy polskiego wywiadu wojskowego odgrywał radiowywiad, który był nowoczesnym środkiem uzyskiwania wartościowych informacji nie tylko o charakterze wojskowym, ale również politycznym i ekonomicznym. W latach dwudziestych polscy kryptolodzy nie mieli kłopotów z łamaniem niemieckich szyfrów transpozycyjnych. Problemy pojawiły się dopiero po wprowadzeniu w Reichswehrze elektromechanicznej maszyny szyfrującej o nazwie Enigma. Uznawana była ona przez Niemców za niezawodny środek w przekazywaniu tajnych informacji, bowiem gwarantowała możliwość ich kodowania w astronomicznej wprost liczbie kombinacji. W 1928 r. zostały podjęte przez polski wywiad wojskowy pierwsze prace nad złamaniem Enigmy. Dopiero zatrudnienie w komórce radiowywiadu, zajmującej się łamaniem szyfrów niemieckich, uzdolnionych matematyków Jerzego Różyckiego, Henryka Zygalskiego i Mariana Rejewskiego przyniosło przełom. Od 1933 r. Polacy zaczęli regularnie czytać niemieckie depesze szyfrowane przy użyciu Enigmy. Materiał pozyskiwany z tego źródła był różnorodny. Dotyczył m.in. rozbudowy niemieckiego potencjału militarnego, brutalnej rozprawy Hitlera z dowództwem SA, remilitaryzacji Nadrenii, zaangażowania III Rzeszy w wojnę domową w Hiszpanii czy też operacji zajęcia w marcu 1938 r. przez Wehrmacht Austrii. Sytuacja uległa zmianie we wrześniu i w grudniu 1938 r., kiedy Niemcy wprowadzili nową procedurę szyfrowania. Nie oznacza to, że od końca 1938 r. do wybuchu wojny nie czytano Enigmy. Odczytywano przede wszystkim depesze niemieckich organów bezpieczeństwa, gdzie nie obowiązywała nowa procedura szyfrowania. 1 VIII $1939 \mathrm{r}$. również w sieci SD nastapiła całkowita zmiana procedury, której nie zdążono już rozpracować. Wybrane informacje szyfrowane za pomoca Enigmy były jednak czytane do ostatnich dni przed wybuchem wojny. W obliczu zbliżającego się konfliktu oraz niemożności przezwyciężenia trudności technicznych, wymagających znacznych nakładów pracy i finansów, przerastających możliwości polskiego Biura Szyfrów, podjęto decyzję o ujawnieniu tajemnicy Enigmy francuskiej i brytyjskiej służbie kryptologicznej.

${ }^{52}$ Z.J. Kapera, Przekazanie aliantom tajemnicy Enigmy..., s. 95-100; M. Grajek, op. cit., s. 141; P. Kołakowski, Czas próby..., s. 280-281. Już w czasie II wojny światowej Brytyjczycy w swoim ośrodku łamania kodów w Bletchley Park, głównie za sprawą wybitnego matematyka i kryptologa Alana Turinga, rozbudowali teoretyczne i przede wszystkim praktyczne rozwiązania związane z Enigmą i maszynowym szyfrowaniem korespondencji, stworzone przez pracowników polskiego Biura Szyfrów. 


\section{On the Operation of the Polish Radio Intelligence on the German Direction in the 1930s}

An important place within the Polish military intelligence work was occupied by radio intelligence, which was a modern means of obtaining valuable information of both a military, political and economic nature. In the 1920s, Polish cryptologists had no problems with breaking German transposition codes. Problems emerged only after Reichswehr introduced an electro-mechanical encryption device called Enigma. The Germans regarded it as a reliable means of transmitting secret information, as it offered the possibility to encode it in an astronomical number of combinations. It was in 1928 that the Polish military intelligence undertook the first works on breaking the Enigma code. But it was not until the gifted mathematicians, Jerzy Różycki, Henryk Zygalski, and Marian Rejewski, were employed by the radio intelligence unit dealing with breaking German codes that the breakthrough came. From 1933 on, Poles were regularly reading German messages encrypted with Enigma. The material obtained from this source was diverse. It concerned, among other things, the expansion of the German military potential, Hitler's brutal purge of the SA leaders, the remilitarisation of the Rhineland, and the Third Reich's involvement in the Spanish civil war or the annexation of Austria by the Wehrmacht in March 1938. The situation changed in September and December 1938, when the Germans introduced a new encryption procedure. This does not mean that the Enigma code was not read from the end of 1938 until the war outbreak. It was mainly the German security authorities' dispatches that were read where the new encryption procedure was not in force. On 1 August 1939, there was also a complete procedure change in the Security Services (SD) network, and this had not been worked out. However, some information encrypted with Enigma was decoded until the last days before the outbreak of the war. In the face of the impending conflict and the impossibility to overcome the technical difficulties, requiring considerable labour and financial resources, exceeding the Polish Cypher Bureau's capabilities, a decision was taken to disclose the secret of Enigma to the French and British cryptologic services.

\section{Bibliografia}

Ciechanowski J.S., Polski wktad w ztamanie niemieckiej maszyny szyfrujacej Enigma, w: Marian Rejewski 1905-1980. Życie Enigma pisane, Bydgoszcz 2005, s. 99-126.

Ciechanowski J.S., Tebinka J., Wspótpraca kryptologiczna Enigma, w: Polsko-brytyjska wspótpraca wywiadowcza podczas II wojny światowej, t. I: Ustalenia Polsko-Brytyjskiej Komisji Historycznej, red. T. Dubicki, D. Nałęcz, T. Stirling, Warszawa 2004, s. $443-461$.

Grajek M., Enigma. Bliżej prawdy, Poznań 2007.

Kapera Z.J., Łamanie szyfrów Enigmy przez Polaków. Mity i prawda, „Przegląd Historyczno-Wojskowy" 2005, nr spec. 5 .

Kapera Z.J., Marian Rejewski pogromca Enigmy, Kraków-Mogilany 2005.

Kapera Z.J., Paryż 1939: tajna konferencja kryptologów alianckich, w: Polski wywiad wojskowy 1918-1945. Materiały, red. P. Kołakowski, A. Pepłoński, Toruń 2006, s. 411-422.

Kapera Z.J., Poznański kurs szyfrów obcych w 1929 r., w: Wywiad wojskowy II Rzeczypospolitej. Materiały, red. P. Kołakowski, A. Pepłoński, Kraków 2011, s. 97-113.

Kapera Z.J., Przekazanie aliantom tajemnicy Enigmy (Pyry, lipiec 1939), „Prace Komisji Historii Wojen i Wojskowości Polskiej Akademii Umiejętności” 2009, t. V.

Kołakowski P., Czas próby. Polski wywiad wojskowy wobec groźby wybuchu wojny w 1939 roku, Warszawa 2012. 
Kołakowski P., Między Warszawa a Praga. Polsko-czechosłowackie stosunki wojskowo-polityczne 1918-1939, Warszawa 2009.

Łukomski G., Poznańskie poczatki „Enigmy”, „Mars” 2001, t. X.

Marian Rejewski 1905-1980. Życie Enigma pisane, Bydgoszcz 2005.

Michulec R., Ku wrześniowi 1939, Gdynia 2008.

West N., MI-6. Operacje brytyjskiej Tajnej Stużby Wywiadu 1905-1945, tłum. R. Brzeski, Warszawa 2000.

Woytak R., Werble historii, Bydgoszcz 1999.

Woźny A., Niemieckie przygotowania do wojny z Polska w ocenach polskich naczelnych wtadz wojskowych w latach 1933-1939, Warszawa 2000.

Piotr Kolakowski - prof. dr hab., Akademia Pomorska w Słupsku. Prace badawcze koncentruje na zagadnieniach związanych z działalnością polskiego wywiadu wojskowego i obcych służb specjalnych w okresie międzywojennym, a także na stosunkach politycznych oraz wojskowych ze szczególnym uwzględnieniem relacji polsko-czechosłowackich w tym okresie. Specjalizuje się również w badaniach nad historią ziem polskich w czasie II wojny światowej i zwalczaniem Polskiego Państwa Podziemnego przez sowiecki aparat bezpieczeństwa. E-m ail: kolakowski.piotr@wp.pl.

Piotr Kolakowski - Prof. Dr. hab., employee of the Pomeranian University in Słupsk. He fosuses his research interests on problems related to operations of Polish military intelligence and foreign special services in the interwar period as well as on political and miltary relations, in particular Polish-Czechoslovak relations at this time. He also specialises in research into the history of Polish lands during World War II and suppression of the Polish Underground State by the Soviet security apparatus. E-mail: kolakowski.piotr@wp.pl. 